\title{
A Saprolegnia parasitica challenge system for rainbow trout: assessment of Pyceze as an anti-fungal agent for both fish and ova
}

\author{
T. G. Pottinger*, J. G. Day
}

NERC Institute of Freshwater Ecology, Windermere Laboratory, Far Sawrey, Ambleside, Cumbria, LA22 0LP, United Kingdom

\begin{abstract}
A reproducible Saprolegnia parasitica spore delivery system was developed and demonstrated to be effective in providing a sustained spore challenge for up to $10 \mathrm{~d}$. Treatment of rainbow trout with slow-release intraperitoneal implants containing cortisol resulted in chronically elevated blood cortisol levels and rendered the fish susceptible to infection by S. parasitica when exposed to the spore challenge. Sham-implanted fish were not susceptible to infection. Bronopol (2-bromo-2-nitropropane-1,3-diol), formulated as Pyceze, was effective in protecting predisposed fish from infection by $S$. parasitica when administered as a daily bath/flush treatment at concentrations of $15 \mathrm{mg} \mathrm{l}^{-1}$ and greater. Pyceze was also demonstrated to protect fertilised rainbow trout ova from $S$. parasitica challenge when administered as a daily bath/flush treatment at concentrations of between 30 and $100 \mathrm{mg}$ $\mathrm{l}^{-1}$. Pyceze appears to qualify as a safe and effective replacement for malachite green and formalin in the prevention of fungal infections in the aquaculture environment.
\end{abstract}

KEY WORDS: Saprolegnia $\cdot$ Fungal infection - Salmonid $\cdot$ Bronopol $\cdot$ Pyceze $\cdot$ Cortisol

\section{INTRODUCTION}

Mycotic infections of farmed fish, primarily by water moulds or pseudofungi of the genus Saprolegnia, represent a significant economic and welfare problem. Sexually mature broodstock and fertilised ova of salmonid fish (Oncorhynchus sp., Salmo sp.) are particularly susceptible to Saprolegnia, as are other cultured species such as channel catfish Ictalurus punctatus (Bly et al. 1992). This state of affairs has been exacerbated by existing and anticipated restrictions on the use of the most effective fungicide available, malachite green. The n-methylated diaminotriphenylmethane dye malachite green has long been employed as a fungicide and ectoparasiticide (see Alderman 1985, van Heerden et al. 1995 for references). However, concerns regarding the mutagenicity, carcinogenicity, and teratogenicity of malachite green (Meyer \& Jorgenson 1983, Culp \& Beland 1996) have led to restrictions on its use (Alderman 1994, Marking et al. 1994).

There has therefore been significant effort expended to identify a therapeutant which is as effective as mala-

•E-mail: t.pottinger@ife.ac.uk chite green in combating mycotic infections of fish and fish eggs, but is safer for the operator, the fish, and the environment. Among the alternative compounds tested for antifungal activity are sodium chloride (Edgell et al. 1993, Marking et al. 1994, Waterstrat \& Marking 1995, Bly et al. 1996. Schreier et al. 1996), potassium permanganate (Bly et al. 1996), copper sulphate (Bly et al. 1996), formalin (Marking et al. 1994, Waterstrat \& Marking 1995, Bly et al. 1996, Schreir et al. 1996), the herbicides diquat, simazine, hydrothol 191, aquathol K (Bly et al. 1996), iodine (Fitzpatrick et al. 1995), glutaraldehyde (Marking et al. 1994, Fitzpatrick et al. 1995), and hydrogen peroxide (Marking et al. 1994, Fitzpatrick et al. 1995, Waterstrat \& Marking 1995, Schreir et al. 1996).

Formalin is reported to be effective in treating fungal infections on eggs (Waterstrat \& Marking 1995, Schreir et al. 1996) but raises safety concerns in relation to the user and to the environment which render it a far from ideal alternative to malachite green (Marking et al. 1994, Burka et al. 1997). Hydrogen peroxide has also been identified as possessing effective antifungal activity (Marking et al. 1994, Fitzpatrick et al. 1995, Waterstrat \& Marking 1995, Schreir et al. 1996) but 
requires further toxicological and efficacy studies to validate its use at the concentrations found to be most effective. The margin of safety applicable to hydrogen peroxide is reportedly narrow (Burka et al. 1997). To date, no wholly effective alternative treatment to malachite green has been identified.

Bronopol (2-bromo-2-nitropropane-1,3-diol) is a biocide which is widely used as a preservative in medical and pharmaceutical products, cosmetics and shampoos (Bryce et al. 1978, Toler 1985, Kumanova et al. 1989). Following in vitro evaluation (D. J. Alderman unpubl.) and a series of studies carried out at various trout farms within the UK by Vericore Ltd. (J. C. Braidwood, C. Müller, J. L. Hart, R. P. Hunter, unpubl.) preliminary evidence was obtained which suggested that bronopol may be a suitable therapeutic/prophylactic treatment for mycotic infections of salmonid fish and fertilised ova. Bronopol is believed to have a dual toxic action in bacteria, with growth suppression being ascribed to the catalytic oxidation of accessible thiols while cell death is thought to be caused by the generation of free radicals (Shepherd et al. 1988). Because this compound is a broad-spectrum biocide, and presents no serious toxicological hazard to humans (Bryce et al. 1978, Croshaw \& Holland 1984) or fish (Vericore Ltd. unpubl. data), the possible application of bronopol within the aquaculture environment requires thorough investigation. The experiments described in the present paper were designed to expand upon the previously conducted, unpublished studies, and to provide a preliminary assessment of the fungicidal efficacy of bronopol under controlled conditions.

Although salmonid fish are naturally susceptible to Saprolegnia infection at certain stages of their development and most UK waters present a continuous background fungal spore challenge, it was decided that for the purposes of these studies a reproducible disease model would provide the most appropriate approach to quantitatively estimating the efficacy of bronopol in combating Saprolegnia infection. The disease model adopted was composed of 2 elements: (1) a reproducible and controlled Saprolegnia spore challenge; (2) a susceptible fish host. The development and use of this model in assessing the efficacy of bronopol as a fungicide are described. We also describe a preliminary assessment of the use of bronopol in treating mycotic infection of salmonid ova.

\section{METHODS}

Saprolegnia strain employed and stock-culture maintenance regime. Saprolegnia parasitica RAT 1 (RAinbow Trout 1) was isolated by Dr L. G. Willoughby (Freshwater Biological Association) from a diseased rainbow trout (Oncorhynchus mykiss Walbaum) obtained from the Institute of Freshwater Ecology (IFE) hatchery in January 1997. On purification the isolate was examined for diagnostic characters including the development of long fine hairs on the secondary spore cyst (Pickering et al. 1979). The occurrence of this diagnostic feature was taken as confirmation of its identification. Master stock cultures were maintained by routine serial subculture (monthly transfers to fresh mediun) on glucose peptone (GP) agar slopes (Willoughby \& Pickering 1977).

Secondary spore production and development and administration of the infective challenge. Secondary spore suspensions were produced by adapting the method of Willoughby et al. (1983) and Cross \& Willoughby (1989). Dried hemp seeds were sterilised by autoclaving in a $250 \mathrm{ml}$ flask to which an equal volume of distilled water was added. Sterilised seeds were infected with Saprolegnia parasitica by transferring seeds (50 per Petri-dish) into Petri-dishes containing GP agar. The dishes were then inoculated with $S$. parasitica, and incubated for $4 \mathrm{~d}$ at $20^{\circ} \mathrm{C}$. After $4 \mathrm{~d}$ 'bearded' hemp seeds were aseptically transferred to coarse weave muslin bags (50 seeds per bag). The fungal spore challenge was administered to each tank in Expts 1 to 3 by anchoring the muslin bags within $500 \mathrm{ml}$ glass flasks attached 'in-line', via Drechsel bottle heads (Quickfit), to the water supply to each aquarium. In Expt 4 the spore challenge was provided by 10 batches of hemp seeds infected with $S$. parasitica retained within muslin bags anchored within a 10 l plastic bucket which was suspended beneath the inflow of each tank. In Expt 5 incoming water passed through a glass beaker within which were anchored 3 muslin bags each containing fifty $S$. parasitica-infected hemp seeds. The source of the fungal challenge was thus protected from contact with the contents of the tank or trough. A preliminary study (data not shown) confirmed that this approach resulted in an elevation of spores judged adequate to initiate an infection in susceptible fish and in ova.

Quantifying spores produced by the infective challenge: sampling, and processing of samples to germinate secondary spores. The numbers of spores released into the experimental tanks were assayed using a method based on that of Willoughby et al. (1984). Water samples $(500 \mathrm{ml})$ were collected in presterilized bottles directly from each tank. GP medium $(5 \mathrm{ml})$ and antibiotic solution $\left(1 \mathrm{ml} ; 7.5 \mathrm{mg} \mathrm{m}^{-1}\right.$ streptomycin sulphate and $7.5 \mathrm{mg} \mathrm{ml}^{-1}$ Penicillin $\mathrm{G}$ in deionized water; filter sterilized) were aseptically added to each sample. The sample bottles were then resealed and inverted once to ensure that the negatively geotactic spores were uniformly distributed within the sample. Aliquots $(100 \mathrm{ml})$ of this material were asepti- 
cally transferred to sterile glass $250 \mathrm{ml}$ flasks, with the closure protected by a foam bung and covered by an aluminium foil cap. The flasks were then incubated overnight at $7^{\circ} \mathrm{C}$

Enumeration of secondary spores. Assay flasks were manually shaken to ensure uniform distribution of the germinated spores; replicate $1 \mathrm{ml}$ samples from duplicate assay flasks were then transferred to a Sedgewick-Rafter cell (Fisher Scientific Ltd.) and examined/enumerated, under phase contrast microscopy ( $\times 50$ magnification). A mean germinating spore density was obtained from a minimum of 4 separate counts on samples derived from each of the tanks in the study.

Fish. Rainbow trout (hatched February 1996, IFE Stirling strain) were maintained in four $1500 \mathrm{l}$ outdoor circular glassfibre stock tanks (1.8 m diameter), each supplied with a constant flow of Windermere lake water (25 $1 \mathrm{~min}^{-1}$ ) (Windermere Lake, Cumbria, UK). Each tank contained approximately 250 fish. Fish were fed 3 d per week with commercial feed (Trouw Aquaculture Standard Expanded) at the manufacturers recommended (daily) rate according to fish size and water temperature.

Administration of implants. Fish were transferred from the experimental aquaria to a bucket containing anaesthetic (2-phenoxyethanol; 1:2000) and given an intraperitoneal injection of molten coconut oil $(0.5 \mathrm{ml})$ containing a suspension of steroid (cortisol and/or testosterone; Sigma; see below for details of dose).

Statistical analysis. Significant treatment-related differences in mean fungal infection scores in Expts 3 , 4 and 5 were identified by analysis of variance (Genstat) with mean scores for fish within each tank providing replication within treatment groups. Significant differences between treatments were determined using the estimated standard error of the difference between means.

Expt 1. Comparison of cortisol and testosterone as immunosuppressants. This study was carried out to establish whether the susceptibility of rainbow trout to infection by Saprolegnia parasitica from an enhanced spore challenge could be increased by treatment with the steroid hormones cortisol and testosterone. It is well established that cortisol is an immunosuppressant in fish. Both under conditions of chronic stress when blood cortisol levels are elevated naturally, and following the administration of exogenous cortisol to otherwise unstressed fish, an increased susceptibility to disease, including mycotic infection, is observed (Pickering \& Pottinger 1989). In addition, the frequency of mycotic infection in salmonids, particularly males, increases dramatically during the spawning period (Richards \& Pickering 1978, Pickering \& Christie 1980), and androgen- dependent changes in the integument have been suggested to contribute to this phenomenon (Cross \& Willoughby 1989). The administration of a predisposing agent to the fish was considered to be less invasive and more reproducible than alternative approaches such as scarification or induction of a 'natural' stress response by exposure to a chronic stressor.

One week pre-study: 8 glass aquaria (50 l), each supplied with a constant flow of lake water $\left(0.21 \mathrm{~min}^{-1}\right.$, $11^{\circ} \mathrm{C}$ ) were populated with juvenile rainbow trout, 8 fish per tank (weight 50 to $100 \mathrm{~g}$ ). On Day 0 of the study 4 treatment groups, 2 tanks group ${ }^{-1}$, each received either $20 \mathrm{mg}$ of cortisol, $20 \mathrm{mg}$ testosterone, $10 \mathrm{mg}$ of each steroid together, or coconut oil only. A spore challenge was administered as described above and the number of spores within each tank was enumerated on Days 0 to 4 and 7 to 11 . The number of fish displaying evidence of mycoses or other disease symptons was recorded daily for $11 \mathrm{~d}$, at which point the study was terminated.

Expt 2. Determination of cortisol implant dose. This study was carried out to optimise the dose of cortisol administered to the fish. Experimental conditions were as for Expt 1 except that the implants administered contained either 5, 10 or $20 \mathrm{mg}$ cortisol. Study duration was $9 \mathrm{~d}$ with a spore challenge present from Day 0 . Spores were counted in samples collected from each tank on Days 0, 4, 7 and 9. Fish were inspected daily for evidence of mycotic infection or other disease symptoms

Expt 3. Range-finding trial-determination of the effective concentration range of bronopol. This study was carried out to evaluate the effects of dose and duration of exposure to bronopol on Saprolegnia parasitica using challenged, predisposed, fish. Seven day pre-study: 20 glass aquaria (50 l) supplied with a constant flow of Windermere lake water (flow rate 31 $\mathrm{min}^{-1}$ ) were each populated with 5 rainbow trout (weight $134 \pm 8.3 \mathrm{~g}$; mean $\pm \mathrm{SEM}, \mathrm{n}=30$ ). On Day 0 fish were given cortisol-containing implants (20 $\mathrm{mg} \mathrm{fish}^{-1}$ ) and were marked individually using alcian blue dye administered via a Panjet needleless injector (Wright Dental Group). Fish were distinguished by placing marks adjacent to the left and right pectoral and pelvic fins, and the ventral fin. An additional group of 25 rainbow trout, maintained in a further 5 aquaria, were treated identically. These fish were anaesthetised in groups of 5 on Days $0,1,3,6$, and 10. A blood sample was removed from the caudal vessels of each fish with a heparinized syringe for the subsequent determination of blood cortisol levels. Blood was kept on ice until centrifuged; plasma was removed and frozen at $-20^{\circ} \mathrm{C}$ until required for assay. Cortisol was determined according to Pickering \& Pottinger (1987). The spore challenge was administered to each tank as described 
for Expt 1 and spore numbers within each tank were enumerated on Days 3 and 10, immediately prior to the administration of the bronopol.

Bronopol (2-bromo-2-nitropropane-1, 3-diol) was provided as a $50 \%$ solution in glycol (Pyceze; Vericore Ltd.). On Days 0 to 10 Pyceze was administered to the test tanks to provide the following nominal concentrations of bronopol, in quadruplicate; $0,2,5,15,30 \mathrm{mg}$ $1^{-1}$. The water supply to each tank was switched off immediately prior to the administration of the bronopol. In 2 tanks of each treatment group, the water was reconnected $15 \mathrm{~min}$ after administration of the bronopol, in the remaining 2 tanks water was reconnected 60 min after dosing. Additional aeration was provided to each tank for the duration of the dosing.

pH was determined on Days 3 and 7 (Jenway model $3050 \mathrm{pH}$ meter). Bronopol levels were determined on Days 8 and 9. Samples were collected from the $60 \mathrm{~min}$ exposure tanks at 5 and 55 min after the addition of bronopol and from the $15 \mathrm{~min}$ exposure tanks $5 \mathrm{~min}$ after the introduction of bronopol. A $500 \mathrm{ml}$ water sample was removed from each test tank. A $0.25 \mathrm{ml}$ aliquot of $85 \%$ orthophosphoric acid solution was added and the sample was thoroughly mixed. Approximately $100 \mathrm{ml}$ of the stabilised sample were stored chilled before being assayed for bronopol content. Dissolved bronopol concentrations were determined by HPLCUV according to method reference MBR/97/7 with a limit of detection of $7.47 \mathrm{mg} \mathrm{l}^{-1}$. Analyses were conducted at the analytical laboratories of Vericore Ltd.

The degree of mycotic infection apparent on each fish was recorded daily ( 0 : absent; 1 : mild; 2 : moderate; 3: severe; 4 : dead). The scoring was carried out by an operator with no prior knowledge of the treatment administered to each tank. Severely infected fish were removed and humanely killed.

Expt 4. Confirmation of effective concentration of bronopol. This study was carried to evaluate under semi-field conditions the efficacy of the doses identified as effective in the previous study. One week prestudy: 30 trout (weight $246 \pm 19 \mathrm{~g}$; mean \pm SEM, $\mathrm{n}=10$ ) were transferred to each of 8 experimental tanks (flow rate $10 \mathrm{l} \mathrm{min}^{-1}$, volume $500 \mathrm{l}$ ). On Day 0 of the study each fish received a $30 \mathrm{mg}$ cortisol implant. A larger implant was employed to maintain proportionality to fish size which was approximately $50 \%$ larger than the fish employed to establish the dose regime. Spore numbers were enumerated on Days 3 and 10, immediately prior to the administration of the bronopol, as described above.

On Days 0 to 14 , pairs of tanks received $0,10,15$, or $20 \mathrm{mg} \mathrm{l}^{-1}$ of bronopol. The water supply to each tank was turned off approximately 2 min prior to administration of the test substance and was reconnected $30 \mathrm{~min}$ after administration of bronopol.
Dissolved oxygen levels were measured daily (OxyGuard Handy Mk III portable DO meter) and pH was determined on Days 2 and 7. On Day 7, 2 water samples were removed from each tank for the determination of bronopol levels.

Because it was not possible to carry out assessment of levels of mycotic infection on individual fish within the tanks during the study, an assessment of the degree of infection of each fish was made on Day 15. During Days 0 to 14, any dead fish were removed from the tanks. On Day 15, the surviving fish were anaesthetized before being killed by a blow to the head. Each fish was inspected and scored according to the level of mycotic infection present as described above.

Expt 5. The effects of Pyceze on the growth of Saprolegnia parasitica on fertilised rainbow trout ova. This experiment was carried out to provide a preliminary assessment of the efficacy of bronopol in combating $S$. parasitica infection of fertilised rainbow trout eggs. Eggs were stripped from anaesthetized ovulated female rainbow trout and fertilised with milt from males of the same age and strain. The fertilised eggs were transferred to each of 2 mesh-bottomed egg trays $(0.4 \times 0.4 \times 0.14 \mathrm{~m})$ within each of 12 troughs $(3.5 \times 0.4 \times 0.16 \mathrm{~m})$ such that each trough contained a total of $\sim 9000$ eggs. Care was taken to ensure that each fertilised pool of eggs was equally represented within each trough. Each trough was supplied with a constant flow of lake water $\left(51 \mathrm{~min}^{-1}\right)$. Pyceze was administered to the troughs daily, for $21 \mathrm{~d}$. The water supply to each trough was switched off and Pyceze was mixed with the water within the trough to provide final nominal concentrations of $5,20,30,50$ and $100 \mathrm{mg} \mathrm{l}^{-1}$ of bronopol. Each dose was administered to duplicate troughs which, together with 2 control troughs receiving no bronopol, provided a total of 6 treatments. After $30 \mathrm{~min}$, the water supply was reconnected. On a daily basis, the eggs in each tray were inspected for evidence of mycotic infection by an operator with no prior knowledge of the treatment administered to each tank and scored as 0 : no obvious infection; 1: 1 to 5 eggs infected; 2 : $>10$ eggs $<10 \%$ coverage; $2.5:>10 \%<50 \%$ coverage $3:>50 \%<75 \%$ coverage; $3.5:>75 \%<100 \%$ coverage; $4: 100 \%$ coverage. During the course of the study no dead or infertile eggs were removed and the trays were not physically disturbed. The dissolved oxygen concentration and water temperature were recorded daily in each trough and $\mathrm{pH}$ was recorded from each trough on Days 7 and 18. On Days 3 and 15, the numbers of spores within each trough were enumerated as described above. On Day 12, water samples were removed from each trough and treated as described above for the determination of bronopol concentrations. 
Expt 6. The effects of Pyceze on the growth of Saprolegnia parasitica in vitro. As a consequence of the observations made during the studies described above, i.e. that bronopol killed spores at concentrations below the maximum nominal (during washout of the dose), this experiment was carried out to establish the concentrations of bronopol which inhibit spore production, spore germination, and vegetative growth of $S$. parasitica. The strain of $S$. parasitica employed was the same as that used for the fish challenge studies. Forty-two single hemp seeds, colonised with $S$. parasitica as detailed above, were transferred inividually to flasks containing $100 \mathrm{ml}$ of sterile lake water. After $48 \mathrm{~h}$ incubation at $7^{\circ} \mathrm{C}$ Pyceze was administered to the flasks, in replicate groups of 6 flasks, to give the concentration range $2,5,10,15,20,30 \mathrm{mg} \mathrm{l}^{-1}$ of bronopol together with 6 control flasks which received no bronopol. After $30 \mathrm{~min}$ incubation at $7^{\circ} \mathrm{C}$ a $1.0 \mathrm{ml}$ aliquot of medium was removed from 3 flasks at each concentration and transferred to the enumeration system to determine the number of spores present. The hemp seeds from these flasks were washed in sterile lake water and transferred to $100 \mathrm{ml}$ of sterile lake water in clean flasks to assess the capacity of the colonies for continued spore production following bronopol treatment. Hemp seeds from the remaining 3 flasks from each bronopol treatment group were washed in sterile lake water and transferred to sterile Petri-dishes containing GP agar to assess the capacity of the colonies for hyphal/mycelial growth following bronopol treatment.

\section{RESULTS}

\section{Expt 1. Comparison of cortisol and testosterone as immunosuppressants}

The mean spore levels $\left(1^{-1}\right)$ for each of the treatment groups, and the cumulative incidence of infection on the experimental fish within each experimental group are shown in Fig. 1. Spore concentrations were low in all tanks until between Days 2 and 3 when marked increases were observed rising from background levels of 100 to 250 spores $\mathrm{l}^{-1}$ on Day 0 to $4000-6000$ spores $\mathrm{l}^{-1}$ on Days 3 and 4 . In the tanks in which no infected fish were observed (control, testosteronetreated) spore numbers declined consistently until the termination of the study (Fig. 1a,c). However, in the tanks in which infected fish were observed (Fig. 1b,d), high spore numbers were sustained for longer. No evidence of disease was apparent in any group until Day 7 of the study, at which point fungal lesions were observed on fish within the cortisol-treated (Fig. 1b) and cortisol+testosterone-treated groups (Fig. 1d). After
$11 \mathrm{~d}$ exposure to the challenge $44 \%$ of cortisol-treated and $38 \%$ of cortisol+testosterone-treated fish had either died or were showing significant levels of mycotic infection. Inspection of the fish revealed no evidence of bacterial lesions either externally or internally. Microscopic examination of material isolated from the infected fish confirmed that Saprolegnia parasitica was the cause of infection. The fish were not screened for ectoparasites but no gross symptoms were evident either on the body surface or gills. On the basis of these data it was decided that cortisol implantation was an appropriate method with which to predispose the experimental fish to infection with $S$. parasitica.
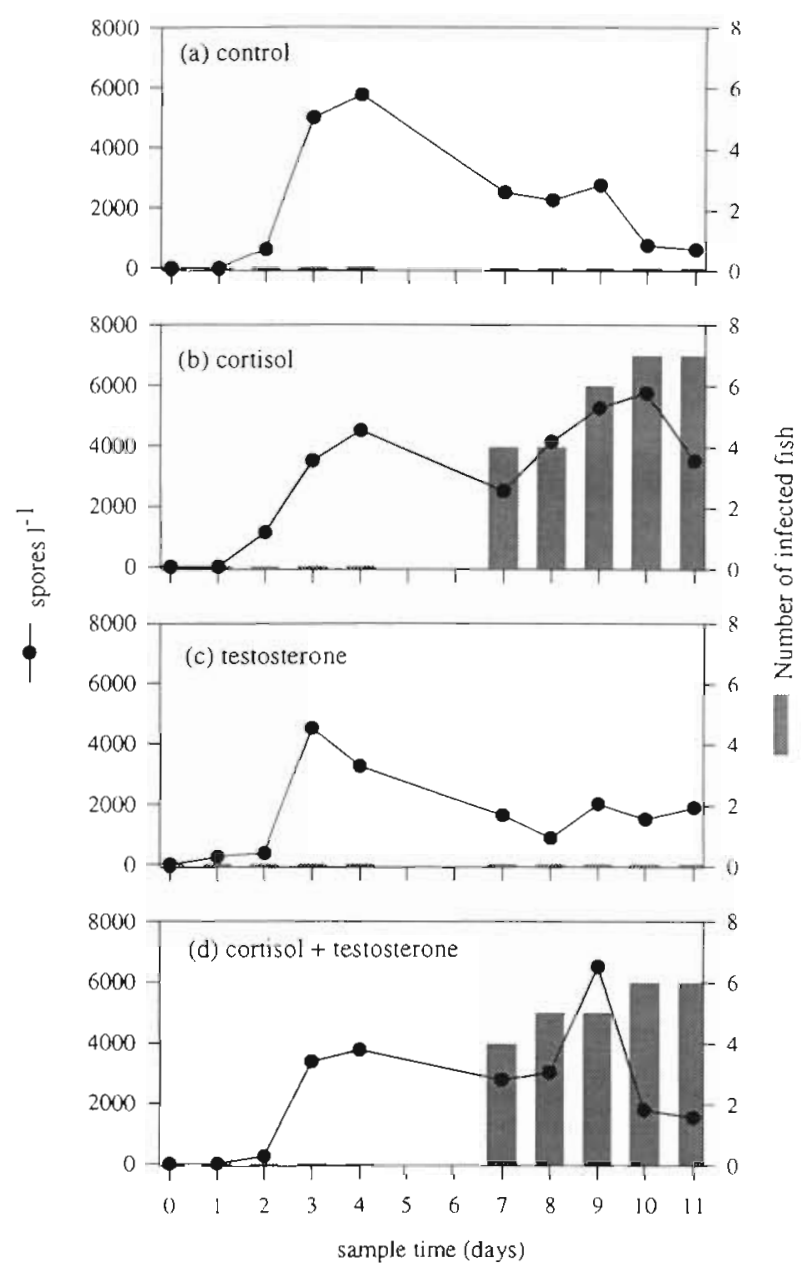

Fig. 1. Expt 1. Saprolegnia parasitica infecting rainbow trout. Mean concentration of $S$. parasitica spores and total number of fish displaying fungal infection in pairs of duplicate tanks containing fish implanted with (a) $0.5 \mathrm{ml}$ of coconut oil alone, or $0.5 \mathrm{ml}$ coconut oil containing $20 \mathrm{mg}$ (b) cortisol, (c) testosterone, (d) cortisol+testosterone and exposed to a continuous spore challenge. Each spore estimate represents the mean of 2 determinations in each replicate tank. Numbers of fish within each treatment group which displayed any evidence of fungal infection are denoted by the solid bars 


\section{Expt 2. Determination of cortisol implant dose}

The mean spore densities $\left(1^{-1}\right)$ for each of the treatment groups, and the cumulative incidence of infection on the experimental fish within each experimental group are shown in Fig. 2. The mean spore levels achieved in each tank after introduction of the in-line inoculum and the rate of increase were similar to those observed during Expt 1 ( 2000 to 4000 spores $1^{-1}$ within $4 \mathrm{~d}$ ). However, numbers of spores dramatically increased to a maximum of $>20000 \mathrm{l}^{-1}$ in the tanks containing fish which had received $20 \mathrm{mg}$ cortisol implants and in which the highest levels of mycotic infection were observed (Fig. 2d). The first evidence of
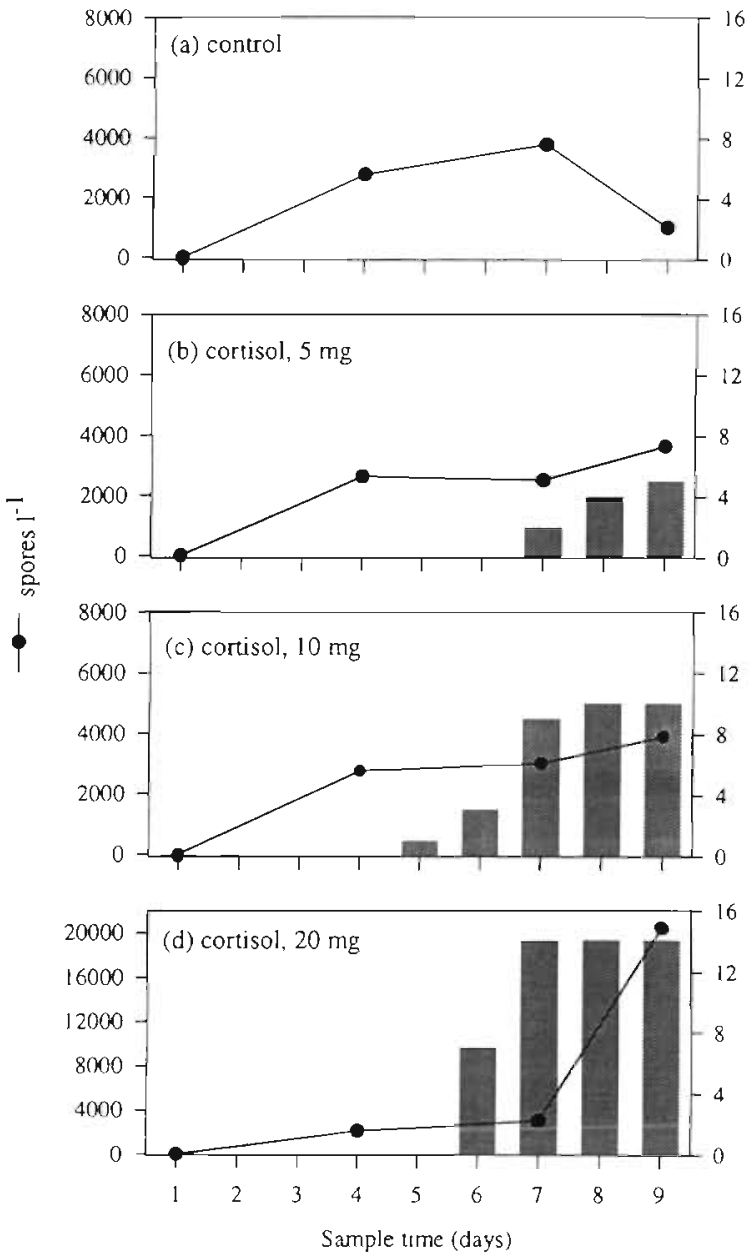

Fig. 2. Expt 2. Saprolegnia parasitica infecting rainbow trout. Mean concentration of $S$. parasitica spores and total number of fish displaying fungal infection in pairs of duplicate tanks containing fish implanted with (a) $0.5 \mathrm{ml}$ of coconut oil alone, or $0.5 \mathrm{ml}$ coconut oil containing (b) $5 \mathrm{mg}$, (c) $10 \mathrm{mg}$, (d) $20 \mathrm{mg}$ cortisol and exposed to a continuous spore challenge. Each spore estimate represents the mean of 2 determinations in each replicate tank. Numbers of fish within each treatment group which displayed any evidence of fungal infection are denoted by the solid bars mycotic infection was visible by Days 5 to 6 (Fig. 2), similar to the lag between the onset of the challenge and infection which was observed in Expt 1. There was a clear dose-dependent relationship between the amount of cortisol administered to the fish and the level of infection which was subsequently observed following spore challenge. In the groups receiving 5 , 10 , and $20 \mathrm{mg}$ cortisol 31,63 and $88 \%$ of the fish were infected, respectively. No infection was observed in either of the control, vehicle-implanted groups. As was the case for Expt 1, no evidence of bacterial infection or ectoparasitic problems were observed in any of the experimental groups.

\section{Expt 3. Range-finding trial-determination of the effective concentration range of bronopol}

Blood cortisol levels for the group of cortisolimplanted fish which were sampled at intervals during this experiment are presented in Fig. 3. Maximum cortisol levels were observed within $24 \mathrm{~h}$ of implantation, rising from a pre-implantation value of $0.4 \pm 0.1 \mathrm{ng}$ $\mathrm{ml}^{-1}(\mathrm{n}=5)$ to $569 \pm 35 \mathrm{ng} \mathrm{ml}^{-1}$ within $24 \mathrm{~h}$ and thereafter declining steadily to a level still markedly elevated above that in unimplanted fish after $10 \mathrm{~d}$ (137 \pm $8 \mathrm{ng} \mathrm{ml}^{-1}$; Fig. 3). The concentration of spores detected within $3 \mathrm{~d}$ of the introduction of the challenge was $\sim 3000 \mathrm{l}^{-1}$, similar to that observed after this period in Expts 1 and 2, and numbers were consistent between treatments, and between exposure times (Fig. 4a,b). However, after $10 \mathrm{~d}$, greater variability in the concentration of spores present was observed between treatment groups; high spore counts were present in the

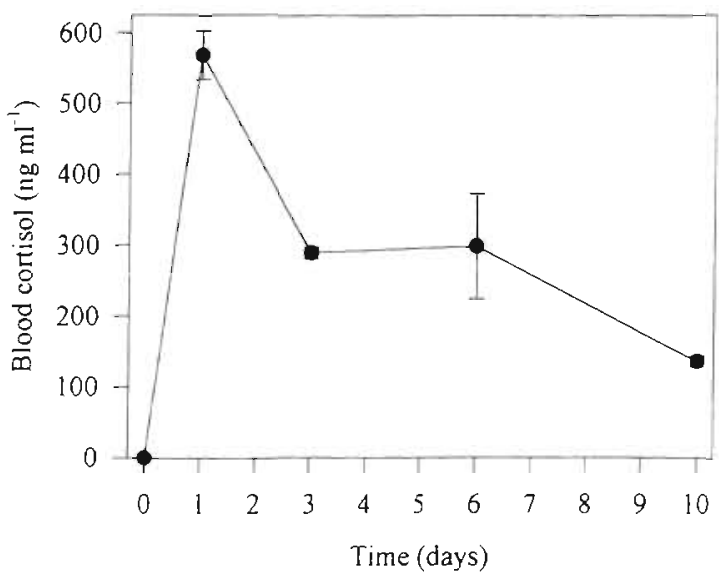

Fig. 3. Expt 3. Oncorhynchus mykiss. Blood cortisol levels immediately prior to implantation and at intervals following implantation in rainbow trout which received $0.5 \mathrm{ml}$ coconut oil implants containing $20 \mathrm{mg}$ cortisol. Each point is the mean \pm SEM, $n=5$ 
control and low bronopol dose tanks $\left(0,2,5 \mathrm{mg}^{-1}\right)$ while in the high bronopol dose tanks $\left(15,30 \mathrm{mg} \mathrm{l}^{-1}\right)$ numbers of spores had declined to $<1000 \mathrm{l}^{-1}$.

The concentrations of bronopol detected by direct assay of samples collected from each tank are presented in Table 1. Overall, there is good agreement between nominal and actual concentrations although the assay sensitivity precluded accurate measurement of bronopol concentrations in the 2 lowest treatments. Water temperature during the course of the study increased gradually from 14.5 to $16.3^{\circ} \mathrm{C}$ by Day 10 and $\mathrm{pH}$ was 6.4.

No evidence of mycoses was observed in any treatment until Day 4, at which point low levels of infection (scored 'present') were observed in the tanks receiving 0,2 , and $5 \mathrm{mg} \mathrm{l}^{-1}$ of bronopol for both 15 and $60 \mathrm{~min}$ (Figs. $5 \& 6$ ). Levels of infection increased steadily in these tanks for the remainder of the study. No infection was observed throughout the course of the study in tanks receiving bronopol at 15 and $30 \mathrm{mg} \mathrm{l}^{-1}$ for $60 \mathrm{~min}$

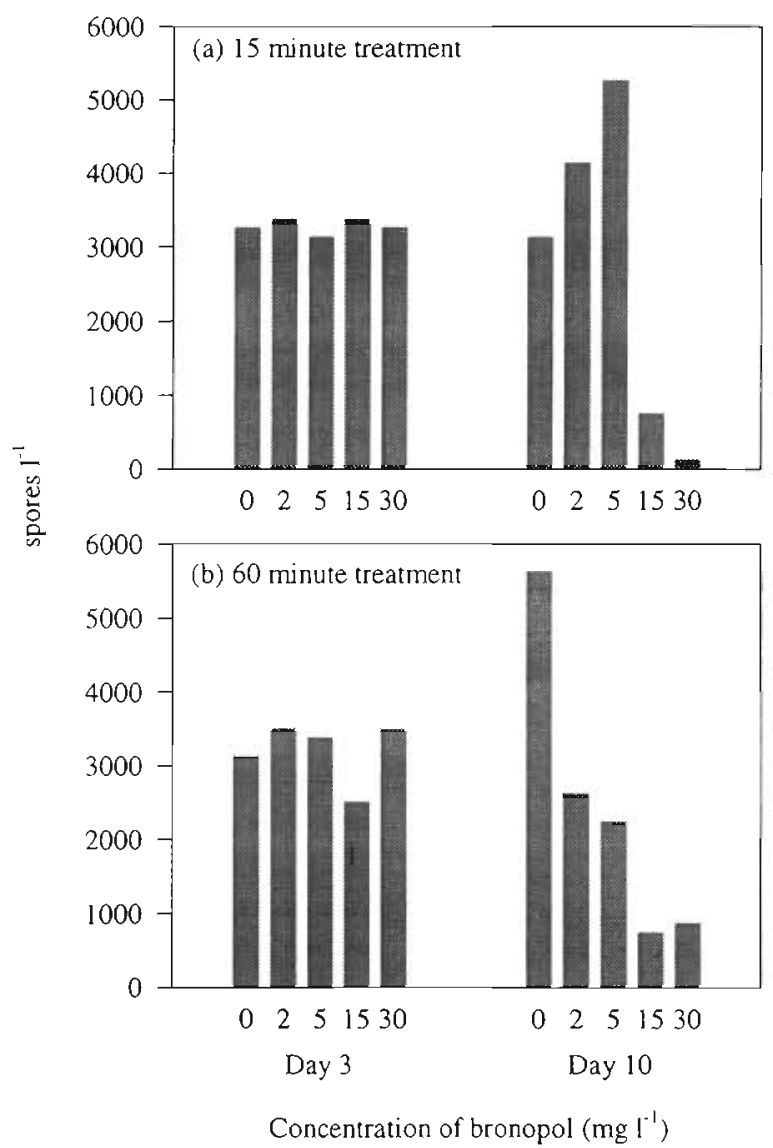

Fig. 4. Expt 3. Saprolegnia parasitica. Mean concentration of spores on Day 3 and Day 10 in duplicate tanks receiving various doses of bronopol for either (a) $15 \mathrm{~min}$ or (b) $60 \mathrm{~min}$ combined with a continuous spore challenge. Each spore estimate represents the mean of 2 determinations in each replicate tank
Table 1. Expt 3. Concentrations of bronopol in the test aquaria $(50$ 1) at intervals after administration. conc. = concentration, $\mathrm{ND}=$ not detectable (limit of detection $=7.5 \mathrm{mg} \mathrm{l}^{-1}$ )

\begin{tabular}{|lccc|}
\hline $\begin{array}{l}\text { Duration of } \\
\text { treatment } \\
(\text { min) }\end{array}$ & $\begin{array}{c}\text { Time of } \\
\text { sample re- } \\
\text { moval after } \\
\text { start of treat- } \\
\text { ment (min) }\end{array}$ & $\begin{array}{c}\text { Nominal conc. } \\
\text { of bronopol } \\
\left(\mathrm{mg} \mathrm{l}^{-1}\right)\end{array}$ & $\begin{array}{c}\text { Actual conc. } \\
\text { of bronopol } \\
\left(\mathrm{mg} \mathrm{l}^{-1}\right)\end{array}$ \\
60 & +5 & 0 & \\
60 & +5 & 2 & $\mathrm{ND}$ \\
60 & +5 & 5 & $\mathrm{ND}$ \\
60 & +5 & 15 & ND \\
60 & +5 & 30 & $28.7,15.2$ \\
60 & +55 & 0 & $\mathrm{ND}$ \\
60 & +55 & 2 & $\mathrm{ND}$ \\
60 & +55 & 5 & $\mathrm{ND}$ \\
60 & +55 & 15 & $15.6,14.6$ \\
60 & +55 & 30 & $28.9,29.9$ \\
15 & +5 & 0 & $\mathrm{ND}$ \\
15 & +5 & 2 & ND \\
15 & +5 & 5 & ND \\
15 & +5 & 15 & $13.5,14.6$ \\
15 & +5 & 30 & $28.7,29.0$ \\
\hline
\end{tabular}

(Fig. 6) and only low levels of infection were observed in tanks receiving bronopol at these doses for $15 \mathrm{~min}$ (Fig. 5). Saprolegnia parasitica was confirmed to be present on infected fish by culturing and examining

Range-finding trial - 15 minutes exposure

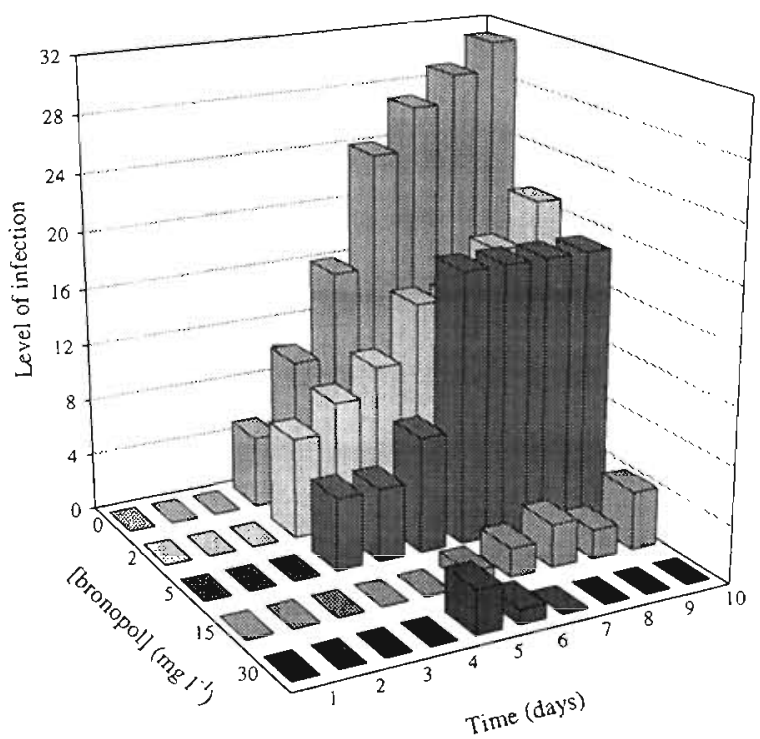

Fig. 5. Expt 3. Saprolegnia parasitica infecting rainbow trout. Level of fungal infection (summed for all fish; scored as 0: absent; 1 : mild; 2 : moderate; 3 : severe $; 4$ : fish dead) in groups of rainbow trout ( 5 fish per tank, 10 fish per treatment) exposed to a continuous $S$. parasitica spore challenge and treated daily with bronopol at concentrations of $0,2,5,15$ or $30 \mathrm{mg} \mathrm{l}^{-1}$ for $15 \mathrm{~min}$ 
Range-finding trial - 60 minutes exposure

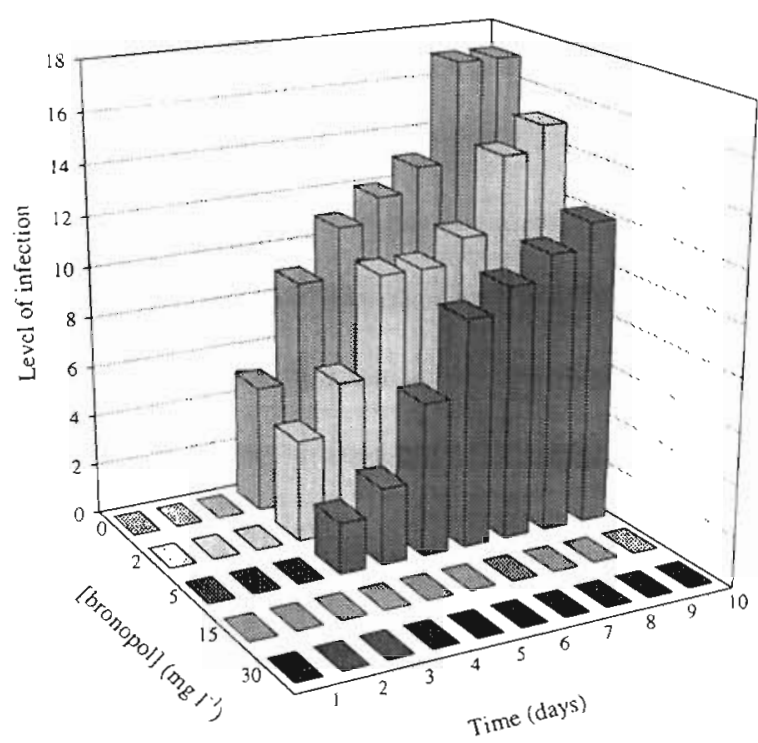

Fig. 6. Expt 3. Saprolegnia parasitica infecting rainbow trout. Level of fungal infection (summed for all fish; scored as 0 : $a b$ sent; 1 : mild; 2 : moderate 3 : severe; 4 : fish dead) in groups of rainbow trout ( 5 fish per tank, 10 fish per treatment) exposed to a continuous $S$. parasitica spore challenge and treated daily with bronopol at concentrations of $0,2,5,15$ or $30 \mathrm{mg} \mathrm{l}^{-1}$ for $60 \mathrm{~min}$

isolates removed from infected fish during the study. ANOVA revealed that the levels of infection in fish receiving $2 \mathrm{mg} \mathrm{l}^{-1}$ bronopol for $15 \mathrm{~min}$ were significantly lower than those of the untreated fish $(\mathrm{p}<0.001)$ but not different to those of fish receiving $5 \mathrm{mg} \mathrm{l}^{-1}$ bronopol. The infection scores for fish receiving 15 and $30 \mathrm{mg} \mathrm{l}^{-1}$ bronopol for $15 \mathrm{~min}$ were both significantly lower than for groups receiving the lower doses $p<$ $0.001)$. At $60 \mathrm{~min}$ exposure, there was no significant difference between the level of infection in the untreated groups and the lowest dose of bronopol. However, the infection levels in the groups receiving 5, 15 and $30 \mathrm{mg} \mathrm{l}^{-1}$ bronopol were all significantly lower than those in the controls ( $p<0.001$ ).

\section{Expt 4. Confirmation of effective concentration of bronopol}

Water temperature during this experiment varied between 7.1 and $9.1^{\circ} \mathrm{C}$. $\mathrm{pH}$ was consistently within the range 6.3 to 6.7 . Dissolved oxygen levels were within the range 6.5 to $10.4 \mathrm{mg} \mathrm{l}^{-1}$. The concentrations of bronopol detected by direct assay of water samples collected during this study are presented in Table 2. Overall, the actual concentrations achieved were below the intended nominal figures of 10,15 and $20 \mathrm{mg}$ $\mathrm{l}^{-1}$. At 5 min after dosing the mean levels in each treatment were $8.2,9.4$ and $14.4 \mathrm{mg}^{-1}$ and after $25 \mathrm{~min}$ the figures were $8.3,10.8$ and $16.4 \mathrm{mg} \mathrm{l}^{-1} ; 70$ to $80 \%$ of the nominal concentrations

There was a clear dose-dependent effect of bronopol on the incidence of mycotic infection on the fish within the treatment tanks. In the control tanks which received no bronopol, almost all fish were heavily infected with Saprolegnia parasitica (total scores of 99.5 and 89.5 compared a theoretical maximum of 120). The presence of $S$. parasitica was confirmed by examining cultures of material isolated from infected fish. Mortality in these groups was high with almost $62 \%$ of the fish dying as a consequence of mycotic infection (Fig. 7a). No evidence of internal or external bacterial lesions was observed in any fish during the study. Nor was there any evidence of excessive ectoparasite infestation. The cause of death was therefore assumed to be the Saprolegnia infection. In contrast, no mortality was observed among the fish receiving bronopol treatment at 15 and $20 \mathrm{mg} \mathrm{l}^{-1}$ (Fig. 7a) and only a limited amount of mycotic infection was observed on 5 fish from a total of 60 in the tanks receiving bronopol at $15 \mathrm{mg} \mathrm{I}^{-1}$ at the end of the study (Fig. $7 \mathrm{C}$ ). Only 1 fish from the 60 fish receiving bronopol at $20 \mathrm{mg} \mathrm{l}^{-1}$ displayed evidence of Saprolegnia infection at the completion of the study. The fungal scoring system employed in the study, which weights the extent of mycelial coverage and occurrence of mortality, provides a clear picture of the efficiency of bronopol treatment at 15 and $20 \mathrm{mg} \mathrm{l}^{-1}$ with scores of 1 and 7 , respectively, compared to scores of 99.5 and 89.5 for the control tanks (Fig. 7c). Overall, the mean fungal scores for fish in the control tanks were significantly greater than for all 3 bronopol treated tanks $(p<0.001)$ and the scores for fish in the group receiving $10 \mathrm{mg} \mathrm{l}^{-1}$ bronopol were significantly greater than those in the 2 highest dose groups ( $p<0.05)$. There was no significant difference between fungal scores in the 2 groups receiving the highest bronopol doses.

Table 2. Expt 4. Concentrations of bronopol in the test tanks (500 l) at intervals after dosing on Day 7 of the study. Two measurements were made from each of 2 replicate tanks at 5 and 25 min after the addition of bronopol. conc. $=$ concentration, $\mathrm{ND}=$ not detectable (limit of detection $=7.5 \mathrm{mg} \mathrm{l}^{-1}$ )

\begin{tabular}{|lcc|}
$\begin{array}{l}\text { Nominal conc. } \\
\text { of bronopol } \\
\left(\mathrm{mg} \mathrm{l}^{-1}\right)\end{array}$ & $\begin{array}{c}\text { Actual conc of } \\
\text { bronopol }\left(\mathrm{mg} \mathrm{l}^{-1}\right) \\
\text { at }+5 \mathrm{~min}\end{array}$ & $\begin{array}{c}\text { Actual conc of } \\
\text { bronopol }\left(\mathrm{mg} \mathrm{I}^{-1}\right) \\
\text { at }+25 \mathrm{~min}\end{array}$ \\
\hline 0 & $\mathrm{ND}$ & $\mathrm{ND}$ \\
10 & $8.3,8.8 ; 7.8,7.8$ & $8.5,8.6 ; 8.1,8.0$ \\
15 & $7.8,9.9 ; 10.0,10.0$ & $10.5,10.6 ; 10.2,11.9$ \\
20 & $14.6,15.9 ; 15.8,11.1$ & $13.8,16.7 ; 17.3,17.6$ \\
\hline
\end{tabular}



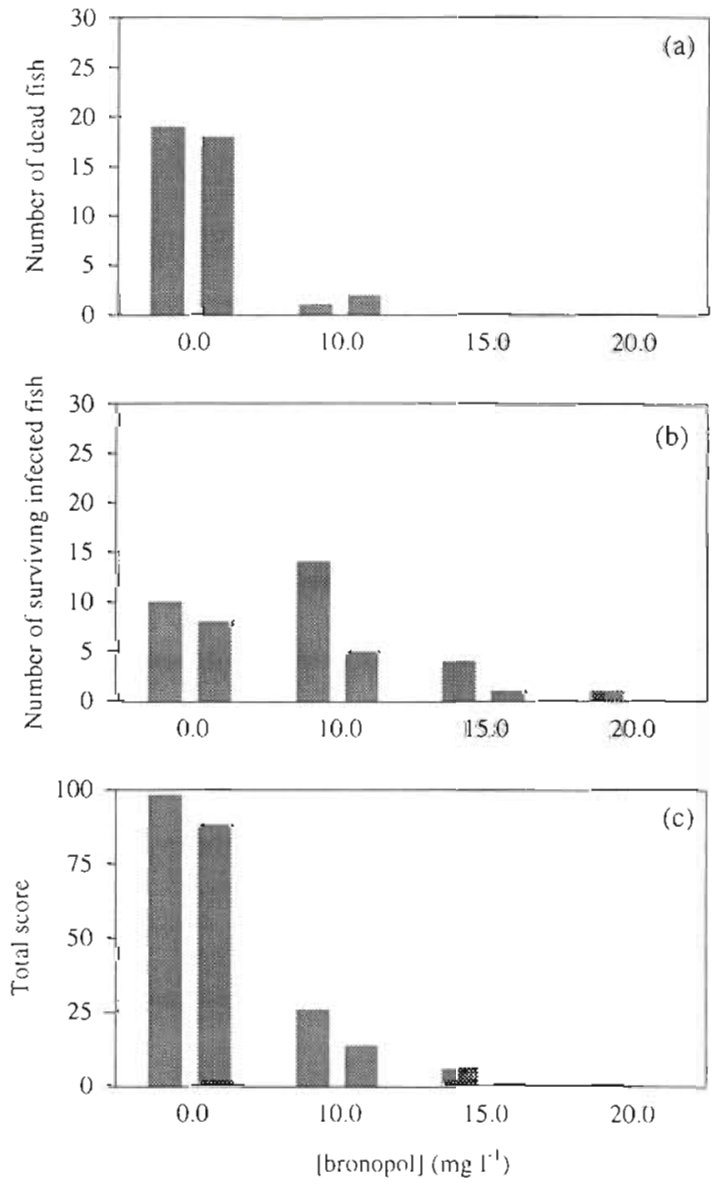

Fig. 7. Expt 4. Saprolegnia parasitica infecting rainbow trout (a) Total mortality at the end of the experimental period; (b) total number of infected fish surviving at the end of the experimental period and (c) the total fungal infection score summed for all fish in each tank at the end of the experimental period (scored as 0 : absent; 1 : mild; 2 : moderate; 3 : severe; 4: fish dead) among rainbow trout exposed to a constant $S$. parasitica spore challenge and treated daily for $14 \mathrm{~d}$ with bronopol at concentrations of $0,10,15$ or $20 \mathrm{mg} \mathrm{l}^{-1}$. Each bar represents the result for 1 of 2 duplicate tanks per treatment (30 fish per tank)

Expt 5. The effects of Pyceze on the growth of Saprolegnia parasitica on fertilised rainbow trout ova

The spore challenge system was successful in sustaining a substantial concentration of spores in the troughs during the course of the experiment; mean spore numbers on Days 3 and 15 were $1393 \pm 119$ spores $\mathrm{l}^{-1}$ and $500 \pm 98$ spores $\mathrm{l}^{-1}$, respectively (mean \pm SEM, $\mathrm{n}=12$ ). Water temperature was $5.3^{\circ} \mathrm{C}$ at the start of the experiment and rose gradually to $6.9^{\circ} \mathrm{C}$ on Day 21. Dissolved oxygen levels were within the range 11 to $12 \mathrm{mg} \mathrm{l}^{-1}$ and $\mathrm{pH}$ was within the range 6.7 to 7.7 . Bronopol concentrations measured in the troughs following dosing on Day 12 are presented in Table 3.
Evidence of mycotic infection was first noted on Day 7 of the study on eggs receiving $20 \mathrm{mg} \mathrm{l}^{-1}$ of bronopol daily and within 2 days was apparent in the 0 and $2 \mathrm{mg} \mathrm{l}^{-1}$ groups (Fig. 8). The initial infections were associated with dead eggs, those which appeared opaque and white in colour rather than the translucent yellow/orange of live eggs. We did not observe primary infection of live eggs although the mycelial mat which was initially associated with dead eggs spread with time to engulf live eggs also. By the end of the study period the control trays receiving no bronopol displayed up to $75 \%$ coverage with mycelium. In contrast, in trays receiving $100 \mathrm{mg} \mathrm{l}^{-1}$ bronopol the infection was restricted to fewer than 10 individual eggs or 2 or 3 small clumps of eggs. Low levels of infection were also observed in trays receiving $30 \mathrm{mg} \mathrm{l}^{-1}$ bronopol although in trays receiving $50 \mathrm{mg} \mathrm{l}^{-1}$ infection coverage was actually slightly greater. A variety of fungi/pseudofungi including Leptomitus sp. and Saprolegnia sp. were identified to genus level in samples taken from troughs containing infected eggs; however, S. parasitica was the dominant organism recovered. Analysis of the data set by ANOVA revealed that the level of infection was significantly reduced, relative to the controls, by all treatments $(p<$ 0.001 ) except $5 \mathrm{mg} \mathrm{l}^{-1}$ which was statistically indistinguishable from the $0 \mathrm{mg} \mathrm{l}^{-1}$ group.

\section{Expt 6. The effects of Pyceze on the growth of Saprolegnia parasitica in vitro}

Assay of spore germination, following treatment with Pyceze, indicated that the response of Saprolegnia parasitica to bronopol was dose dependant (Table 4). At relatively low levels of bronopol (2 to $10 \mathrm{mg} \mathrm{l}^{-1}$ ) only minor reductions in spore levels were observed, whereas higher doses (15 and $20 \mathrm{mg} \mathrm{l}^{-1}$ ) led to $>50 \%$ reduction in spore level and the highest dose tested (30 $\mathrm{mg} \mathrm{l}^{-1}$ ) resulted in $\sim 80 \%$ reduction in spore level

Table 3. Expt 5. Concentrations of bronopol in egg-rearing troughs after dosing on Day 12 of the study. The means of single measurements made from each of 2 replicate troughs at 5 and 25 min after the addition of bronopol are presented. $\mathrm{ND}=$ not detectable (limit of detection $=7.5 \mathrm{mg} \mathrm{l}^{-1}$ )

\begin{tabular}{|cc|}
$\begin{array}{c}\text { Nominal concentration of } \\
\text { bronopol (mg l-1})\end{array}$ & $\begin{array}{c}\text { Actual concentration of } \\
\text { bronopol }\left(\mathrm{mg} \mathrm{l}^{-1}\right)\end{array}$ \\
\hline 0 & ND \\
5 & 18.2 \\
20 & 39.7 \\
30 & 46.2 \\
50 & 59.1 \\
100 & 116.7 \\
\hline
\end{tabular}


Egg challenge trial - 30 minutes exposure

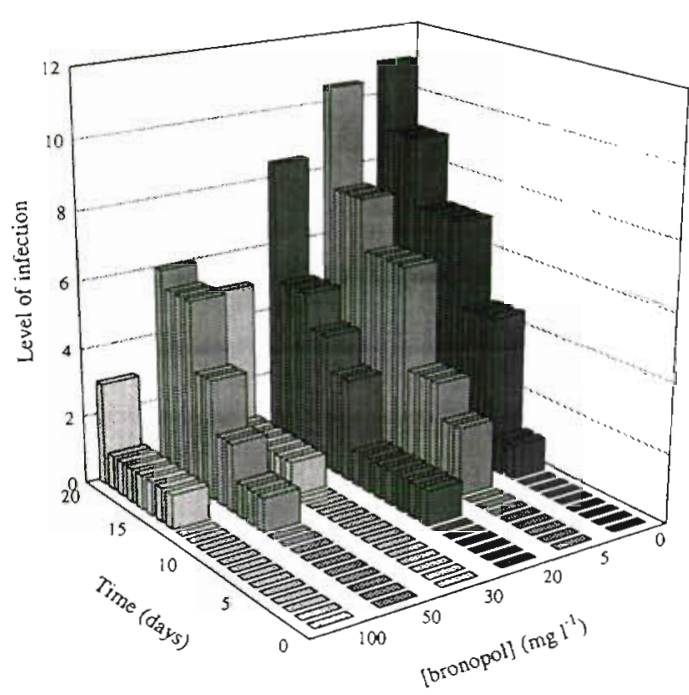

Fig. 8. Expt 5. Saprolegnia parasitica infecting rainbow trout Fungal infection score in duplicate egg-rearing troughs, each containing 2 trays with a total of -9000 eggs per trough, treated daily for $21 \mathrm{~d}$ with bronopol at concentrations of 0,5 , $20,30,50,100 \mathrm{mg} \mathrm{l}^{-1}$. Each bar represents the combined score for the duplicate trays within 2 replicate troughs

(Table 4). Furthermore, 1 flask treated with $30 \mathrm{mg} \mathrm{l}^{-1}$ bronopol, failed to yield any spores capable of germinating. At all dose levels employed, the transfer of $\sim 1 \%$ of the bronopol present, leading to an initial concentration in the assay flasks of 0 to $0.3 \mathrm{mg} \mathrm{l}^{-1}$, had no influence on the ability of the spores present to germinate (Table 4).

After washing bronopol-exposed hemp seeds in sterile water, and transferring to sterile solid medium, Saprolegnia parasitica was recovered from all of the treated seeds (Table 5). No obvious difference between the growth of control material and that treated

Table 4. Expt 6. Saprolegnia parasitica spore germination following bronopol treatment. Each value is the mean \pm SEM of 2 determinations on each of 3 replicates $(n=6)$

\begin{tabular}{|lcc|}
\hline $\begin{array}{l}\text { Bronopol conc. } \\
\left(\mathrm{mg} \mathrm{l}^{-1}\right)\end{array}$ & $\begin{array}{c}\text { No. of spores }\left(\times 10^{-3} \mathrm{l}^{-1}\right) \\
\text { Post-bronopol } \\
\text { treatment }\end{array}$ & $\begin{array}{c}\text { Residual bronopol } \\
\text { assay }\end{array}$ \\
\hline 0 & $10.3 \pm 1.0$ & $13.6 \pm 1.0$ \\
2 & $8.0 \pm 1.3$ & $13.2 \pm 0.2$ \\
5 & $6.8 \pm 3.5$ & $15.8 \pm 1.3$ \\
10 & $8.2 \pm 0.6$ & $13.6 \pm 0.6$ \\
15 & $4.3 \pm 1.0$ & $13.6 \pm 0.6$ \\
20 & $4.5 \pm 1.7$ & $13.0 \pm 0.9$ \\
30 & $2.0 \pm 2.0$ & $13.5 \pm 1.0$ \\
a Transfer of 1 ml of bronopol-treated water to the spore in- & \\
duction system to assess whether residual bronopol trans- \\
ferred from the treatment flasks would affect the assay
\end{tabular}

Table 5. Expt 6. Saprolegnia parasitica hyphal growth and spore production following bronopol treatment. Each value is the mean \pm SEM of 2 determinations on each of 3 replicates

$$
(\mathrm{n}=6)
$$

\begin{tabular}{|lcrc|}
\hline $\begin{array}{c}\text { Concentration of } \\
\text { bronopol }\left(\mathrm{mg} \mathrm{l}^{-1}\right)\end{array}$ & $\begin{array}{c}\text { Hyphal growth (mm) } \\
24 \mathrm{~h}\end{array}$ & $72 \mathrm{~h}$ & $\begin{array}{c}\text { Spore production } \\
\left(\text { no. } \times 10^{-3} \mathrm{l}^{-1}\right)\end{array}$ \\
\hline 0 & 3 & 13.5 & $10.2 \pm 0.3$ \\
2 & 3 & 13.5 & $8.8 \pm 0.3$ \\
5 & 3 & 13.0 & $9.5 \pm 1.5$ \\
10 & 3 & 13.5 & $4.8 \pm 2.3$ \\
15 & 3 & 12.5 & $5.5 \pm 0.5$ \\
20 & 1.5 & 9.0 & $3.7 \pm 1.6$ \\
30 & 1.5 & 10.0 & $1.8 \pm 0.3$ \\
& & & \\
\end{tabular}

with bronopol up to $15 \mathrm{mg} \mathrm{l}^{-1}$ was noted (Table 5). However, at higher dose levels the growth rate of $S$. parasitica was reduced, suggesting that the fungal hyphae at the periphery of the hemp seed were killed by the initial treatment (Table 5). Furthermore, treatments employing bronopol at $10 \mathrm{mg} \mathrm{l}^{-1}$ and above had a significant influence on the production of spores (Table 5). The reduction in the capacity of the colony to produce spores was apparently dose dependent, with recoverable spore numbers comparable to those observed in the initial assay (Table 4).

\section{DISCUSSION}

\section{The disease model}

The challenge system employed in these studies was effective in elevating the spore concentration markedly above background levels $\left(\sim 4000\right.$ spores $l^{-1}$ cf. $\sim 150$ spores $\mathrm{l}^{-1}$ ) and in providing a sustained, though declining, challenge for a period of 10 to $14 \mathrm{~d}$. However, we were unable to infect rainbow trout by exposure to the spore challenge without first predisposing the fish to infection by elevating blood cortisol levels using slow-release cortisol implants; shamimplanted control fish did not exhibit evidence of colonisation by Saprolegnia parasitica. Carballo et al. (1995), although employing more invasive techniques than in the present study, also reported that elevated blood cortisol levels were a major factor in successfully inoculating rainbow trout with $S$. parasitica, and it is well-established that cortisol-implanted salmonids display an increased susceptibility to infection by the 'natural' Saprolegnia spore challenge (Pickering \& Duston 1983, Pickering \& Pottinger 1989). Rainbow trout clearly have a very effective protective mechanism preventing the successful attachment and germination of $S$. parasitica spores which is compromised by cortisol administration, allowing $S$. parasitica to act as a primary 
pathogen. This strongly supports earlier assertions that outbreaks of mycotic infection in various species under aquacultural conditions or in the natural environment must normally arise as a consequence of a predisposing/immunosuppressive factor(s) (Bly et al. 1994, Pickering 1994). In the current studies we were surprised to observe no secondary disease problems other than the deliberately induced S. parasitica infections, despite the likely presence of opportunist fish pathogens in the lake water within which the studies were executed. Bly et al. (1992) also reported an absence of bacterial pathogens in catfish suffering from 'winter kill' Saprolegniasis. These authors considered that low water temperatures and the possible production of antimicrobial substances by Saprolegnia may have accounted for the absence of other disease symptoms. It is unlikely that temperature was a factor in preventing bacterial infections in the present studies, particularly during Expt 3 in which water temperatures reached $16^{\circ} \mathrm{C}$.

The elevation of blood androgen levels by the administration of implants containing the steroid testosterone was ineffective in enhancing the susceptibility of trout to Saprolegnia parasitica infection. This is somewhat surprising when the following factors are considered. Sexually mature male and female salmonids show an enhanced vulnerability to mycotic infection (Richards \& Pickering 1978, Pickering \& Christie 1980); testosterone levels are elevated in rainbow trout in both sexes during the spawning period (Pottinger et al. 1996); the androgen 11-ketotestosterone was reported to enhance susceptibility of rainbow trout to $S$. parasitica challenge (Cross \& Willoughby 1989); and testosterone displays apparent suppressive effects on the immune system of salmonid fish (Slater et al. 1995). However, it is possible that the enhanced susceptibility to Saprolegnia infection which is associated with cortisol administration occurs via a mechanism other than suppression of the immune system, or via an immunosuppressive route which is not sensitive to androgen regulation. It is also possible that the teleost androgen 11-ketotestosterone, rather than testosterone: would have been more potent in enhancing susceptibility.

The permissive link between stress and mycotic infections in mammals is well established but as yet the mechanisms underlying the relationship are not fully understood (Mishra et al. 1994). In fish also, the defence mechanisms which afford protection from mycotic infection are not well understood and one can only speculate by what mechanism cortisol renders fish susceptible to Saprolegnia parasitica infection. The 2 defensive strategies suggested to be employed by fish to overcome the challenge presented by pathogenic fungi are (1) the removal of the spore from the surface of the fish before it establishes infection and
(2) inhibition of the growth of the germinating spore within the mucus layer (Pickering \& Willoughby 1982a). It has been shown that the rate of loss of viable spores from the surface of brown trout Salmo trutta L. is rapid, with $95 \%$ of viable spores being removed within $2 \mathrm{~h}$ of exposure (Pickering \& Willoughby $1982 \mathrm{~b}$ ), suggesting that physical removal is an important protective element. Mucus secreted by epidermal cells of brown trout has been reported to provide a nutritive growth medium in vitro for Saprolegnia spores (Willoughby et al. 1983). However, subsequent work suggested that if spores come into contact with mucus while on the surface of the fish, there is an inhibitory effect on growth of the fungus (Wood et al. 1986, 1988). A number of compounds with potentially fungicidal activity have been reported to occur in fish mucus including trypsin, lysozyme, immunoglobulins, and agglutinins (Ourth 1980, Dalmo et al. 1997), some of which might account for inhibitory effects on fungal growth. It is not known whether cortisol has any effects on the dynamics of mucus production by epidermal goblet cells, but given the broad range of effects of cortisol on elements of the specific and non-specific immune system (Barton \& Iwama 1991, Wendelaar Bonga 1997), there is clearly scope for corticosteroid interference with the integumental defence system.

\section{Evaluation of Pyceze}

Pyceze was found to be effective in reducing or preventing mycotic infection in challenged fish. Administered daily, at concentrations of 15 and $30 \mathrm{mg}$ bronopol $\mathrm{l}^{-1}$, a $60 \mathrm{~min}$ bath was completely effective in protecting immunosuppressed rainbow trout from a continuous Saprolegnia parasitica spore challenge (Expt 3). In contrast, untreated fish showed heavy and persistent Saprolegnia infections. When an exposure duration of 15 min was employed, the incidence of infection remained low in the groups receiving bronopol at 15 and $30 \mathrm{mg} \mathrm{l}^{-1}$. When the experiment was repeated in outdoor full-size tanks (Expt 4), bronopol remained effective, at concentrations of 15 and $20 \mathrm{mg} \mathrm{l}^{-1}$, in protecting the immunosuppressed, challenged, fish from $S$. parasitica infection.

It must be noted that the exposure times reported are an underestimate of the actual residence time of bronopol within the experimental tanks because they do not take into account the period required for washout of the residual bronopol from the tanks. In Expt 3 the additional exposure time was significant; within $4 \mathrm{~h}$ of the resumption of water flow the concentration of bronopol would have declined to $11 \mathrm{mg} \mathrm{l}^{-1}$ from a starting point of $30 \mathrm{mg} \mathrm{l}^{-1}$ with a flow rate of $0.2 \mathrm{l}$ $\mathrm{min}^{-1}$ and total volume of $50 \mathrm{l}$. However, in Expt 4, with 
a flow rate of $10 \mathrm{lmin}^{-1}$ and a total volume of $500 \mathrm{l}$, the concentration of bronopol would have declined from a start point of $20 \mathrm{mg} \mathrm{l}^{-1}$ to $<1 \mathrm{mg} \mathrm{l}^{-1}$ within $2.5 \mathrm{~h}$ and within $1 \mathrm{~h}$ would have declined to $5 \mathrm{mg} \mathrm{l}^{-1}$, a concentration with little evident effect on the growth of Saprolegnia parasitica. Nonetheless, viable spores were detected in all treatments within 2 to $4 \mathrm{~h}$ of reestablishing the water supply. The agreement between the estimated most-effective doses in the low-flow small aquarium study (Figs. $5 \& 6$ ) and the higher flow large tank studies (Fig. 7) suggests that the effectiveness of bronopol is not primarily a function of prolonged exposure times but that absolute concentration is critical.

The effects of bronopol in vitro on spore germination, hyphal growth, and spore production were in broad agreement with the results of the fish exposure studies. Germination of spores was reduced by up to $80 \%$ by concentrations of bronopol shown to protect fish from infection (15 to $30 \mathrm{mg} \mathrm{l}^{-1}$ ) but hyphal growth was less affected by exposure to bronopol. Continued growth was observed even following treatment with bronopol at a concentration of $30 \mathrm{mg} \mathrm{l}^{-1}$. Spore production was greatly curtailed at higher concentrations of bronopol also. These results suggest that the role of bronopol in protecting fish from infection may be to prevent the germination of attached spores for sufficiently long to allow their removal by turnover of the mucus layer. The lack of effect on hyphal growth suggests that bronopol will be less effective against an established infection although the marked inhibitory effects of bronopol on spore release suggest that fish with an existing fungal burden would pose less of an infective risk to other fish in the immediate vicinity.

Pyceze was effective in protecting rainbow trout eggs from infection when administered as a single daily $30 \mathrm{~min}$ bath/flush treatment at a concentration of $100 \mathrm{mg}$ bronopol $\mathrm{l}^{-1}$. There was strong evidence from the preliminary experiment that concentrations of 30 and $50 \mathrm{mg} \mathrm{l}^{-1}$ may also offer protection. As is the case for the fish experiments the actual time in contact with bronopol exceeded the duration of the bath period and in the case of the $100 \mathrm{mg} \mathrm{l}^{-1}$ treatment, $2.5 \mathrm{~h}$ would have been required to reduce the residual concentration of bronopol to $<1 \mathrm{mg} \mathrm{l}^{-1}$ after reconnecting the water supply. During the course of this experiment we noted that live eggs were not colonised by Saprolegnia parasitica; initial infections were always associated with dead eggs. After nodes of infection had become established on dead eggs, the expanding mycelial growth engulfed live eggs, ultimately leading to egg mortalities. This is consistent with the observations of Kitancharoen \& Hatai (1996), who reported that live rainbow trout eggs were not susceptible to infection when challenged with any of 4 different isolates of Saprolegnia spp., and Smith et al. (1985), who observed the colonization of live eggs by hyphal contact only, not by spore infection. It has been suggested that nutrient loss from dead eggs is critical in attracting and/or sustaining initial spore contact (Smith et al. 1985) and positive chemotaxis by Saprolegnia zoospores has been demonstrated towards concentration gradients of extracts of live salmonid eggs (Rand \& Munden 1993). The fertilization envelope of viable rainbow trout eggs has been demonstrated to possess antifungal activity (Kudo \& Teshima 1991, Kudo 1992), which is presumably a primary factor in preventing the infection of live eggs by Saprolegnia spores. The presence of lysozyme in the yolk of coho salmon Oncorhynchus kisutch Walbaum eggs may also be of significance in this context (Yousif et al. 1994).

In conclusion, the data reported here provide evidence that bronopol (Pyceze) is an effective therapeutic agent for the preventive treatment of mycotic infections in the aquaculture environment. This compound is a safer alternative to malachite green and formalin, currently considered to be the most effective aquacultural fungicides.

Acknowledgements. The authors gratefully acknowledge the advice and assistance provided by Julian Braidwood, Richard Hunter, Nicola Fraser and Mary Griffiths (Vericore Ltd.) Chemical analyses were carried out by D. A. Thompson (Grampian Pharmaceuticals Ltd.). Audrey Cook (IFE), Toby Carrick (IFE) and Tim Beaumont (Liverpool University) provided technical assistance. Dr L. G. Willoughby (FBA) provided valuable technical advice. This study was jointly funded by Grampian Pharmaceuticals and MAFF under the LINK Aquaculture scheme (Contract TRT01)

\section{LITERATURE CITED}

Alderman DJ (1985) Malachite green: a review. J Fish Dis 8 : $289-298$

Alderman DJ (1994) Control of oomycete pathogens in aquaculture. In: Mueller GJ (ed) Salmon Saprolegniasis. Bonneville Power Administration, Portland, p 111-129

Barton BA, Iwama GK (1991) Physiological changes in fish from stress in aquaculture with emphasis on the responses and effects of cortisol. Annu Rev Fish Dis 1:3-26

Bly JE, Lawson LA, Dale DJ, Szalai AJ, Durborow RM, Clem LW (1992) Winter saprolegniasis in channel catfish. Dis Aquat Org 24:25-33

Bly JE, Lawson LA, Abdel-Aziz ES, Clem LW (1994) Channel catfish, Ictalurus punctatus, immunity to Saprolegnia sp. In: Tave D, Tucker CS (eds) Recent developments in catfish aquaculture. Haworth Press, New York, p 35-50

Bly JE, Quiniou SMA, Lawson LA, Clem LW (1996) Therapeutic and prophylactic measures for winter saprolegniosis in channel catfish. Dis Aquat Org 24:25-33

Bryce DM, Croshaw B, Hall JE, Holland VR, Lessel, B (1978) The activity and safety of the antimicrobial agent bronopol (2-bromo-2-nitropropan-1,3-diol). J Soc Cosmet Chems 29:3-24

Burka JF, Hammell KL, Horsberg IE, Johnson GR, Rainnie DJ, Speare DJ (1997) Drugs in salmonid aquaculture-a review. J Vet Pharmacol Therapeut 20:333-349 
Carballo M, Muñoz MJ, Cuellar M, Tarazona JV (1995) Effects of waterborne copper, cyanide, ammonia, and nitrite on stress parameters and changes in susceptibility to Saprolegniasis in rainbow trout (Oncorhynchus mykiss). Appl Environ Microbiol 61:2108-21.12

Croshaw B, Holland VR (1984) Chemical preservatives use of bronopol as a cosmetic preservative In: Kabara JJ (ed) Cosmetic and drug preservation. Principles and practice. Marcel Dekker, New York, p 31-62

Cross ML, Willoughby LG (1989) Enhanced vulnerability of rainbow trout (Salmo gairdneri) to Saprolegnia infection, following treatment of the fish with an androgen. Mycol Res 93:379-402

Culp SJ, Beland FA (1996) Malachite green: a toxicological review. J Am Coll Toxicol 15:219-238

Dalmo RA, Ingebrigtsen K, Bøgwald J (1997) Non-specific defence mechanisms in fish, with particular reference to the reticuloendothelial system (RES). J Fish Dis 20: 241-273

Edgell P, Lawseth D, McLean WE, Britton EW (1993) The use of salt solutions to control fungus (Saprolegnia) infestations on salmon eggs. Prog Fish Cult 55:48-52

Fitzpatrick MS, Schreck CB, Chitwood RL, Marking LL (1995) Evaluation of three candidate fungicides for treatment of adult spring chinook salmon. Prog Fish Cult 57:153-155

Kitancharoen N, Hatai K (1996) Experimental infection of Saprolegnia spp. in rainbow trout eggs. Fish Pathol 31: $49-50$

Kudo S (1992) Enzymatic basis for protection of fish embryos by the fertilization envelope. Experientia 48:277-281

Kudo S, Teshima C (1991) Enzyme activities and antifungal action of fertilization envelope extract from fish eggs. J Exp Zool 259:392-398

Kumanova R, Vassileva M, Dobreva S, Manova S, Kupenov L (1989) Evaluating bronopol. Manuf Chem 60:36-37

Marking LL, Rach JJ, Schreier TM (1994) Evaluation of antifungal agents for fish culture. Prog Fish Cult 56:225-231

Meyer FP, Jorgenson TA (1983) Teratological and other effects of malachite green on development of rainbow trout and rabbits. Trans Am Fish Soc 112:818-824

Mishra SK, Segal E, Gunter E, Kurup VP, Mishra J, Murali PS, Pierson DL, Sandovsky-Losica H, Stevens DA (1994) Stress, immunity and mycotic diseases. J Med Vet Mycol 32:379-406

Ourth DD (1980) Secretory IgM, lysozyme and lymphocytes in the skin mucus of the channel catfish, Ictalurus punctatus. Dev Comp Immunol 4:65-74

Pickering AD (1994) Factors which predispose salmonid fish to Saprolegniasis In: Mueller GJ (ed) Salmon Saprolegniasis. Bonneville Power Administration, Oregon, p 67-84

Pickering AD, Christie P (1980) Sexual differences in the incidence and severity of ectoparasitic infestation of the brown trout, Salmo trutta L. J Fish Biol 16:669-683

Pickering AD, Duston J (1983) Administration of cortisol to brown trout, Salmo trutta L., and its effects on the susceptibility to Saprolegnia infection and furunculosis. J Fish Biol 23:163-175

Pickering AD, Pottinger TG (1987) Poor water quality suppresses the cortisol response of salmonid fish to handling and confinement. J Fish Biol 30:363-374

Pickering AD, Pottinger TG (1989) Stress responses and disease resistance in salmonid fish: effects of chronic elevations of plasma cortisol. Fish Physiol Biochem 7:253-258

Pickering AD, Willoughby LG (1982a) Saprolegnia infections of salmonid fish. Fiftieth Annual Report of the Freshwater Biological Association, Ambleside, p 38-48
Pickering AD, Willoughby LG (1982b) Saprolegnia infections of salmonid fish. In: Roberts RJ (ed) Microbial diseases of fish. Academic Press, London, p 271-297

Pickering AD, Willoughby LG, McGrory CB (1979) Fine structure of secondary zoospore cyst cases of Saprolegnia isolates from infected fish. Trans Br Mycol Soc 72:427-436

Pottinger TG, Carrick TR, Hughes SE, Balm PHM (1996) Testosterone, 11-ketotestosterone, and estradiol-17 $\beta$ modify baseline and stress-induced interrenal and corticotropic activity in trout. Gen Comp Endocrinol 104:284-295

Rand TG, Munden D (1993) Chemotaxis of zoospores of two fish-egg-pathogenic strains of Saprolegnia diclina (Oomycotina: Saprolegniaceae) toward salmonid egg chorion extracts and selected amino acids and sugars. J Aquat Anim Health 5:240-245

Richards RH, Pickering AD (1978) Frequency and distribution patterns of Saprolegnia infection in wild and hatcheryreared brown trout Salmo trutta L. and char Salvelinus alpinus (L.). J Fish Dis 1:69-82

Schreier TM, Rach JJ, Howe GE (1996) Efficacy of formalin, hydrogen peroxide, and sodium chloride on fungalinfected rainbow trout eggs. Aquaculture 140:323-331

Shepherd JA, Waigh RD, Gilbert P (1988) Antibacterial action of 2-bromo-2-nitropropane-1,3-diol (bronopol). Antimicrob Agents Chemother 32:1693-1698

Slater CH, Fitzpatrick MS, Schreck CB (1995) Androgens and immunocompetence in salmonids: specific binding in and reduced immunocompetence of salmonid lymphocytes exposed to natural and synthetic androgens. Aquaculture 136:363-370

Smith SN, Armstrong RA, Springate J, Barker G (1985) Infection and colonization of trout eggs by Saprolegniaceae. Trans Br Mycol Soc 85:719-764

Toler JC (1985) Preservative stability and preservative systems. Int J Cosmet Sci 7:157-164

van Heerden E, van Vuren JHJ, Steyn, GJ (1995) LC Lo $_{50}$ determination for malachite green and formalin on rainbow trout (Oncorhynchus mykiss) juveniles. Water S A (Pretoria) $21: 87-94$

Waterstrat PR, Marking LL (1995) Clinical evaluation of formalin, hydrogen peroxide, and sodium chloride for the treatment of Saprolegnia parasitica on fall chinook salmon eggs. Prog Fish Cult 57:287-291

Wendelaar Bonga SE (1997) The stress response in fish. Physiol Rev 77:591-625

Willoughby LG, Pickering AD (1977) Viable Saprolegniaceae spores on the epidermis of the salmonoid fish Salmo trutta and Salvelinus alpinus. Trans Br Mycol Soc 68:91-95

Willoughby LG, McGrory CB, Pickering AD (1983) Zoospore germination of Saprolegnia pathogenic to fish. Trans Br Mycol Soc 80:421-435

Willoughby LG, Pickering AD, Johnson HG (1984) Polycellgel assay of water for spores of Saprolegniaceae (fungi), especially those of the Saprolegnia pathogen of fish. Hydrobiologia 114:237-248

Wood SE, Willoughby LG, Beakes GW (1986) Preliminary evidence for inhibition of Saprolegnia fungus in the mucus of brown trout, Salmo trutta L. following experimental challenge. J Fish Dis 9:557-560

Wood SE, Willoughby LG, Beakes GW (1988) Experimental studies on uptake and interaction of spores of the Saprolegnia diclina-parasitica complex with external mucus of brown trout (Salmo trutta). Trans Br Mycol Soc 90:63-73

Yousif AN, Albright LJ, Evelyn TPT (1994) In vitro evidence for the antibacterial role of lysozyme in salmonid eggs. Dis Aquat Org 19:15-19

Submitted: October 9, 1998; Accepted: January 14, 1999

Proofs received from author(s): May 5, 1999 